\title{
The Constitutionality of Parallel Civil Forfeiture Proceedings and Criminal Prosecutions under the Double Jeopardy Clause in the United States
}

\author{
La constitucionalidad de procedimientos de comiso \\ civil y procesos penales paralelos bajo la cláusula \\ double jeopardy en los Estados Unidos
}

\section{Javier Escobar Veas ${ }^{1}$}

Università Commerciale Luigi Bocconi, Milano, Italia

javier.escobar@mail.udp.cl

http://orcid.org/0000-0001-9266-0396

\begin{abstract}
АвSTRACT: In the Unites States the existence of statutes that allow to declare forfeiture of the property used in certain prohibited ways in civil proceedings without the general safeguards of criminal law is an extended legal practice. This parallel law enforcement system, however, has raised several constitutional discussions. One of these debates concerns the compatibility of the parallel system with the double jeopardy clause: does the double jeopardy clause bar the government from bringing a civil forfeiture proceeding against a defendant that has previously been convicted in a criminal court for the same offence? The aim of the present article is studying the evolution of the case law of the Supreme Court of the United States on the constitutionality of parallel civil forfeiture proceedings and criminal prosecutions under the double jeopardy clause, analysing the current state of the jurisprudence and its possible further developments.
\end{abstract}

Kerwords: Civil forfeiture; double jeopardy clause; ne bis in idem; prohibition of multiple punishments; excessive fines clause.

1 PhD Candidate in Legal Studies, Università Luigi Bocconi, Italy. LLM in Criminal Law, Universidad Diego Portales, Chile. Professor of Criminal Law, Universidad Mayor, Chile. 
ResUmen: En los Estados Unidos la existencia de leyes que permiten declarar el comiso de la propiedad utilizada en determinadas maneras prohibidas en un procedimiento civil sin las garantías generales del derecho penal es una práctica legal extendida. Este sistema paralelo de cumplimiento del derecho ha suscitado diversas discusiones constitucionales. Una de estas discusiones dice relación con la compatibilidad de este sistema paralelo con la cláusula double jeopardy: ¿prohíbe la cláusula double jeopardy que el gobierno incoe un procedimiento de comiso civil en contra de una persona que haya sido previamente condenada en sede penal por los mismos hechos? El objetivo del presente artículo es estudiar la evolución de la jurisprudencia de la Corte Suprema de Estados Unidos sobre la constitucionalidad de la incoación paralela de procesos penales y procedimientos de comiso civil bajo la cláusula de doble riesgo, analizando el estado actual de la jurisprudencia y sus posibles repercusiones.

Palabras-clave: Comiso civil; cláusula double jeopardy; ne bis in idem; prohibición de sanción múltiple; prohibición de multas excesivas.

Summary: Introduction; 1. Evolution of the Case Law of the Supreme Court on the Constitutionality of Parallel Civil Forfeiture Proceedings and Criminal Prosecutions under the Double Jeopardy Clause; 2. Recalling the Excessive Fines Clause; Conclusions; Bibliography; Table of Cases.

\section{INTRODUCTION}

Asset forfeiture has emerged in the last decades as a major weapon in efforts to combat crime. ${ }^{2}$ In the United States there are several both federal and state statues that allow to declare forfeiture of the property used in certain prohibited ways in civil proceedings. ${ }^{3}$

2 REINHART, Douglas. Applying the Eighth Amendment to Civil Forfeiture After Austin v. United States: Excessiveness and Proportionality. William \& Mary Law Review, v. 36, n. 1, p. 235-268, 1994, p. 236; JOHNSON, Barry L. Purging the Cruel and Unusual: The Autonomous Excessive Fines Clause and Desert-Based Constitutional Limits on Forfeiture after United States v. Bajakajian. University of Illinois Law Review, n. 2, p. 461-516, 2000, p. 462.

3 KLEIN, Susan R. Civil in Rem Forfeiture and Double Jeopardy. Iowa Law Review, v. 82, n. 1, p. 183-274, 1996, p. 195; BATRA, Rishi. Resolving Civil 
On the one hand, criminal forfeiture statutes are enacted to punish criminal defendants following a criminal conviction. Since the criminal proceeding is directed to punish the defendant and criminal forfeitures are actually imposed as part of the criminal sentence, these forfeitures are considered sanctions in personam. ${ }^{4}$ On the contrary, civil forfeiture does not require neither a criminal conviction nor criminal charges against the owner of the property. ${ }^{5}$ Moreover, the jurisdiction in a civil forfeiture proceeding is in rem, therefore the guilt of the owner of the property is not relevant: the case is brought against the property and, in case of conviction, it is the property itself that is deemed guilty. As the Supreme Court has affirmed, civil forfeiture is based on the idea that "the thing is primarily considered the offender". ${ }^{6}$

Regarding the possibility to bring parallel civil forfeiture actions and criminal prosecutions based on the same facts, the Supreme Court has noted that Congress has authorised this option since the earliest years of the United States. ${ }^{7}$ Therefore, the government can prosecute a defendant for a conduct that constitutes a criminal offence punishable

Forfeiture Disputes. University of Kansas Law Review, v. 66, n. 2, p. 399-426, 2017, pp. 401-403.

4 ALBIN, Laurel. Notes: Constitutional Limitations of Civil in Rem Forfeiture and the Double Jeopardy Dilemma: Civil in Rem Forfeiture Constitutes Punishment and Is Subject to Excessive Fines Analysis. Aravanis v. Somerset County, 339 Md. 644, 664 A.2d 888 (1995), Cert. Denied, 116 S. Ct. 916 (1996). University of Baltimore Law Review, v. 26, n. 1, p. 155-199, 1996, pp. 159-160.

5 PIMENTEL, David. Forfeitures and the Eighth Amendment: A Practical Approach to the Excessive Fines Clause as a Check on Government Seizures. Harvard Law \& Policy Review, v. 11, n. 2, p. 541-584, 2017, p. 545; BATRA, Rishi. Resolving Civil Forfeiture Disputes, op. cit., p. 407; TAIFA, Nkechi. Civil Forfeiture vs. Civil Liberties. New York Law School Law Review, v. 39, n. 1-2, p. 95-120, 1994, pp. 98-99; JOHNSON, Barry L. Purging the Cruel and Unusual: The Autonomous Excessive Fines Clause and Desert-Based Constitutional Limits on Forfeiture after United States v. Bajakajian, op. cit., pp. 465-466.

6 Goldsmith-Grant Co. v. United States, 254 U.S. 505, 511 (1921).

7 United States v. Ursery, 518 U.S. 267, 274 (1996); ALBIN, Laurel. Notes: Constitutional Limitations of Civil in Rem Forfeiture and the Double Jeopardy Dilemma: Civil in Rem Forfeiture Constitutes Punishment and Is Subject to Excessive Fines Analysis. Aravanis v. Somerset County, 339 Md. 644, 664 A.2d 888 (1995), Cert. Denied, 116 S. Ct. 916 (1996), op. cit., p. 161. 
by imprisonment and, separately, bringing a civil forfeiture proceeding against the property used in such prohibited conduct. ${ }^{8}$

Because civil forfeiture is declared in a civil proceeding without the traditional safeguards of criminal law ${ }^{9}$ it has been pointed out that the current state of civil forfeiture statutes violate several constitutional guarantees, being thereby criticised from a constitutional point of view. ${ }^{10}$ Moreover, since civil forfeiture is declared in a civil proceeding the government does not need to prove its case beyond a reasonable doubt. ${ }^{11}$ Instead, the standard of proof ${ }^{12}$ in civil litigation is either the preponderance of the evidence, which translates into "more-likely-thannot", ${ }^{13}$ or clear and convincing evidence, which could be translated as much-more-likely-than-not. ${ }^{14}$

8 NELSON, Caleb. The Constitutionality of Civil Forfeiture. Yale Law Journal, v. 125, n. 8, p. 2446-2518, 2016, p. 2490.

9 For instance, Andrew Subin remarks that in civil forfeiture proceedings the property owner is not entitled to a court appointed attorney and even it is unclear whether the owner has the right to a jury. See SUBIN, Andrew L. The Double Jeopardy Implications of In Rem Forfeiture of Crime-Related Property: The Gradual Realization of a Constitutional Violation. Seattle University Law Review, v. 19, n. 2, p. 253-288, 1996, p. 253-254.

TAIFA, Nkechi. Civil Forfeiture vs. Civil Liberties, op. cit., p. 95.

BATRA, Rishi. Resolving Civil Forfeiture Disputes, op. cit., p. 407; SUBIN, Andrew L. The Double Jeopardy Implications of In Rem Forfeiture of Crime-Related Property: The Gradual Realization of a Constitutional Violation, op. cit., pp. 253-254.

12 The Supreme Court has defined the standard of proof as "the degree of certainty by which the factfinder must be persuaded of a factual conclusion to find in favor of the party bearing the burden of persuasion". See Microsoft Corp. v. i4i Ltd. Partnership, 564 U.S. 91, 100 (note 4) (2011).

Colorado v. New Mexico, 467 U.S. 310, 316 (1984); SCHWARTZ, David L., and SEAMAN, Christopher B. Standards of Proof in Civil Litigation: An Experiment from Patent Law. Harvard Journal of Law \& Technology, v. 26, n. 2, p. 429-480, 2013, p. 435.

14 JAMES, Fleming. Burdens of Proof. Virginia Law Review, v. 47, n. 1, p. 51-70, 1961, p. 54; SCHWARTZ, David L., and SEAMAN, Christopher B. Standards of Proof in Civil Litigation: An Experiment from Patent Law, op. cit., pp. 435437; CLERMONT, Kevin M. Procedure's Magical Number Three Psychological Bases for Standards of Decision. Cornell Law Review, v. 72, n. 6, p. 11151156, 1987, p. 1119. 
One of the constitutional debates regarding civil forfeiture concerns the question whether the double jeopardy clause precludes the government from bringing parallel civil forfeiture proceedings and criminal prosecutions for the same offence. ${ }^{15}$

Since there is currently a tendency to include civil forfeiture mechanisms in national legal systems, studying the case law of the United States Supreme Court on this matter is relevant because the United States is probably the legal system in which civil forfeiture has been further analysed and discussed. The present article, therefore, aims to study the evolution of the case law of the Supreme Court of the United States on the constitutionality of parallel civil forfeiture proceedings and criminal prosecutions under the double jeopardy clause, analysing the current state of the jurisprudence and its possible further developments.

\section{Evolution of the Case law of the Supreme Court on the Constitutionality of Parallel Civil Forfeiture Proceedings and Criminal Prosecutions under the Double Jeopardy Clause}

The Fifth Amendment provision against double jeopardy is one of the basic protections afforded by the United States Constitution. ${ }^{16}$ The Fifth Amendment reads in part: "Nor shall any person be subject for the same offense to be twice put in jeopardy of life or limb".

Even though the wording of the double jeopardy clause could suggest that it only applies to proceedings of capital offences, since Ex parte Lange the Supreme Court has held that the constitutional provision applies to all cases where a second criminal punishment is attempted to be inflicted for the same offence. ${ }^{17}$

15 SUBIN, Andrew L. The Double Jeopardy Implications of In Rem Forfeiture of Crime-Related Property: The Gradual Realization of a Constitutional Violation, op. cit., pp. 255-256.

16 SIGLER, Jay A. Federal Double Jeopardy Policy. Vanderbilt Law Review, v. 19, n. 2, p. 375-405, 1966, p. 375.

17 Ex parte Lange, 85 U.S. 163, 173 (1873). See also Hudson v. United States, 522 U.S. 93, 99 (1997); NOLAN, Patrick S. Double Jeopardy's Multipunishment Protection and Regulation of Civil Sanctions after United States v. 
Made applicable to the states in Benton v. Maryland through the Fourteenth Amendment, ${ }^{18}$ the Supreme Court has recognised that the double jeopardy clause provides three different protections: "It protects against a second prosecution for the same offense after acquittal. It protects against a second prosecution for the same offense after conviction. And it protects against multiple punishments for the same offense". ${ }^{19}$ With reference to the prohibition of multiple punishments, the Supreme Court recognised it in Ex parte Lange, ${ }^{20}$ when the Court affirmed that there was no doubt that the Constitution "was designed as much to prevent the criminal from being twice punished for the same offence as from being twice tried for it". ${ }^{21}$

Regarding the underlying policies of these three protections, in Green v. United States, the Supreme Court stated: "The underlying idea, one that is deeply ingrained in at least the Anglo-American system of jurisprudence, is that the State with all its resources and power should not be allowed to make repeated attempts to convict an individual for an

Ursery. Marquette Law Review, v. 80, n. 4, p. 1081-1116, 1997, p. 1086; LIMBAUGH, Stephen. The Case of Ex Parte Lange (Or How the Double Jeopardy Clause Lost Its Life or Limb). American Criminal Law Review, v. 36, n. 1, p. 53-86, 1999, p. 54; RUDSTEIN, David. Double Jeopardy: A Reference Guide to the United States Constitution. Praeger, 2004, p. 54.

Benton v. Maryland, 395 U.S. 784, 787 (1969).

North Carolina v. Pearce, 395 U.S. 711, 717 (1969). See also United States v. Wilson, 420 U.S. 332, 343 (1975); Justices of Boston Municipal Court v. Lydon, 466 U.S. 294, 306-307 (1984); Grady v. Corbin, 495 U.S. 508, 516 (1990); United States v. Dixon, 509 U.S. 688, 696 (1993); United States v. Ursery, 518 U.S. 267, 273 (1996); Sattazahn v. Pennsylvania, 537 U.S. 101, 106 (2003); HENNING, Peter J. Precedents in a Vacuum: The Supreme Court Continues to Tinker with Double Jeopardy. American Criminal Law Review, v. 31, n. 1, p. 1-72, 1993, p. 8; ANIELAK, Eric Michael. Double Jeopardy: Protection against Multiple Punishments. Missouri Law Review, v. 61, n. 1, p. 169184, 1996, p. 171; WELLS, Adam C. Multiple-Punishment and the Double Jeopardy Clause: The United States v. Ursery Decision. St. John's Law Review, v. 71, n. 1, p. 153-172, 1997, p. 161.

CARLTON, Christopher W. Cumulative Sentences for One Criminal Transaction Under the Double Jeopardy Clause: Whalen v. United States. Cornell Law Review, v. 66, n. 4, p. 819-841, 1981, p. 821; NOLAN, Patrick S. Double Jeopardy's Multipunishment Protection and Regulation of Civil Sanctions after United States v. Ursery, op. cit., p. 1085.

21 Ex parte Lange, 85 U.S. 163, 173 (1873). See also United States v. Benz, 282 U.S. 304, 307-308 (1931). 
alleged offence, thereby subjecting him to embarrassment, expense and ordeal and compelling him to live in a continuing state of anxiety and insecurity, as well as enhancing the possibility that even though innocent he may be found guilty". ${ }^{22}$

When after a criminal conviction the government seeks to impose a civil sanction on the same defendant for the same conduct, the protection against multiple punishments is called into question. ${ }^{23}$ For the double jeopardy clause to apply in civil forfeiture proceedings two requirements should be met.

In the first place, both the criminal conviction and the civil forfeiture should be "for the same offence". In Blockburger v. United States, the Supreme Court established the same elements test, commonly referred as the Blockburger test. ${ }^{24}$ In this case, the defendant was charged with five counts and the jury convicted him on the second, third and fifth counts only. All these counts charged a sale of drugs to the same purchaser: the second count charged a sale on a specified day of ten grains of the drug not in or from the original stamped package; the third count charged a sale on the following day of eight grains of the drug not in or from the original stamped package; and the fifth count charged the latter sale also as having been made not in pursuance of a written order of the purchaser as required by the statute. The court sentenced the defendant to five years' imprisonment and a fine of $\$ 2,000$ on each count. ${ }^{25}$

22 Green v. United States, 355 U.S. 184, 187-188 (1957). See also Benton v. Maryland, 395 U.S. 784, 795-796 (1969); United States v. Wilson, 420 U.S. 332, 343 (1975); United States v. Jenkins, 420 U.S. 358, 370 (1975); Burks v. United States, 437 U.S. 1, 11 (1978); United States v. Di Francesco, 449 U.S. 117, 127-128 (1980); Ohio v. Johnson, 467 U.S. 493, 498-499 (1984); Morris v. Mathews, 475 U.S. 237, 247 (1986); Blueford v. Arkansas, 566 U.S. 599, 605 (2012), among others.

23 SUMMERS, Brian L. Double Jeopardy: Rethinking the Parameters of the Multiplicity Prohibition. Ohio State Law Journal, v. 56, n. 5, p. 1595-1618, 1995, p. 1595; ALBIN, Laurel. Notes: Constitutional Limitations of Civil in Rem Forfeiture and the Double Jeopardy Dilemma: Civil in Rem Forfeiture Constitutes Punishment and Is Subject to Excessive Fines Analysis. Aravanis v. Somerset County, 339 Md. 644, 664 A.2d 888 (1995), Cert. Denied, 116 S. Ct. 916 (1996), op. cit., p. 186. 
The question the Supreme Court had to resolve was whether the defendant had been convicted twice for the same offence. The Court held that "where the same act or transaction constitutes a violation of two distinct statutory provisions, the test to be applied to determine whether there are two offences or only one, is whether each provision requires proof of a fact which the other does not". ${ }^{26}$ The test emphasizes the elements of the two offences, since each of them must require something that the other does not in order to be regarded as different offences. ${ }^{27}$ If each of the offences requires proof of a fact that the other does not, they should be deemed as separate offences, notwithstanding a substantial overlap in the proof offered to establish the crimes. ${ }^{28}$

In the second place, for the double jeopardy clause to apply to civil forfeiture proceedings the civil forfeiture sought by the government should constitute criminal punishment. ${ }^{29}$ Due to the difficulties to clearly define the notion of criminal punishment this second requirement is probably the one that more discussion has generated. At the same time, the case law of the Supreme Court on this topic has not been at all exempt from critics.

In the following it will be studied the evolution of the case law of the Supreme Court on this last requirement.

\subsection{Various Items of Personal Property et al. v. United States.}

The first case on the constitutionality of parallel civil forfeiture proceedings and criminal prosecutions under the double jeopardy clause was Various Items of Personal Property et al. v. United States, decided in 1931. In this case, the government brought a civil forfeiture action to

26 Blockburger v. United States, 284 U.S. 299, 304 (1932).

27 AMAR, Akhil, and Jonathan L. Marcus. Double Jeopardy Law after Rodney King. Columbia Law Review, v. 95, n. 1, p. 1-59, 1995, p. 28; MERKL, Taryn A. The Federalization of Criminal Law and Double Jeopardy. Columbia Human Rights Law Review, v. 31, n. 1, p. 175-208, 1999, p. 189.

Iannelli v. United States, 420 U.S. 770, 785 (note 17) (1975); Lewis v. United States, 523 U.S. 155, 176-177 (Scalia, J., concurring) (1998).

29 SOLOMON, Matthew C. The Perils of Minimalism: United States v. Bajakajian in the Wake of the Supreme Court's Civil Double Jeopardy Excursion Note. Georgetown Law Journal, v. 87, n. 3, 849-886, 1999, p. 855. 
forfeit a distillery, warehouse and denaturing plant on the ground that the defendant had conducted its distilling business with intent to defraud, and had defrauded, the government of the related tax. ${ }^{30}$ The defendant had previously been convicted for the same acts indicated in the civil action. ${ }^{31}$

In the first place, the Supreme Court explained that even though in United States v. La Franca it had held that a civil action to recover a penalty was punitive in character and therefore was barred by the prior conviction of the defendant for the same transaction, ${ }^{32}$ the situation in the present case was different, because it was about a civil proceeding to forfeit property used in committing a criminal offence. ${ }^{33}$ Where a statute has provided a civil proceeding to forfeit property used in committing a criminal offence the property is "primarily considered as the offender, or rather the offense is attached primarily to the thing; and this, whether the offense be malum prohibitum, or malum in se". ${ }^{34}$ In contrast, "in a criminal prosecution it is the wrongdoer in person who is proceeded against, convicted and punished". ${ }^{35}$ The Supreme Court therefore concluded that the double jeopardy clause did not apply to this case because the civil forfeiture was not part of the punishment for the criminal offence. ${ }^{36}$

\subsection{Helvering v. Mitchell: The Statutory Construction Analysis.}

A fundamental decision regarding the notion of criminal punishment was Helvering v. Mitchell. In this case, the defendant was tried

30 Various Items of Personal Property et al. v. United States, 282 U.S. 577, 578 (1931).

31 Various Items of Personal Property et al. v. United States, 282 U.S. 577, 579 (1931).

32 United States v. La Franca, 282 U.S. 568, 575-577 (1931).

33 Various Items of Personal Property et al. v. United States, 282 U.S. 577, 580 (1931).

34 Various Items of Personal Property et al. v. United States, 282 U.S. 577, 580 (1931).

35 Various Items of Personal Property et al. v. United States, 282 U.S. 577, 581 (1931).

36 Various Items of Personal Property et al. v. United States, 282 U.S. 577, 581 (1931). 
for tax evasion and acquitted by the jury. Afterwards, the tax authorities imposed him a civil penalty which amounted to a fifty-percent of his tax deficiency. ${ }^{37}$ The defendant contended that the civil penalty was barred under the double jeopardy clause because it was not a tax sanction, but rather a criminal penalty intended as punishment. ${ }^{38}$

In the first place, the Supreme Court recognised that a civil sanction following a criminal prosecution may be barred by the double jeopardy clause. However, this will only happen if the civil sanction constitutes criminal punishment. ${ }^{39}$ The Supreme Court then explained that since Congress may impose both a criminal and a civil sanction in respect to the same act the question regarding the nature of the sanction is one of statutory construction. ${ }^{40}$ By applying canons of statutory construction, the Court concluded that the statute at stake was intended as civil in nature. The Court stated that the sanction was provided as a safeguard for the protection of the revenue and to reimburse the government the expense of investigation and the loss resulting from the fraud of the taxpayer. ${ }^{41}$ Moreover, the circumstance that Congress provided in a civil statute a distinctly civil procedure for the collection of the additional tax indicated that the sanction in question was intended as civil in nature. ${ }^{42}$

The statutory construction analysis of Helvering v. Mitchell became the standard for the subsequent cases involving the application of the double jeopardy clause to parallel criminal and civil convictions. ${ }^{43}$

37 Helvering v. Mitchell, 303 U.S. 391, 395 (1938).

38 Helvering v. Mitchell, 303 U.S. 391, 398-399 (1938).

39 Helvering v. Mitchell, 303 U.S. 391, 398-399 (1938); NOLAN, Patrick S. Double Jeopardy's Multipunishment Protection and Regulation of Civil Sanctions after United States v. Ursery, op. cit., p. 1087.

40 Helvering v. Mitchell, 303 U.S. 391, 399 (1938).

41 Helvering v. Mitchell, 303 U.S. 391, 401 (1938).

42 Helvering v. Mitchell, 303 U.S. 391, 402 (1938); ANIELAK, Eric Michael. Double Jeopardy: Protection against Multiple Punishments, p. 172.

43 SUMMERS, Brian L. Double Jeopardy: Rethinking the Parameters of the Multiplicity Prohibition. Ohio State Law Journal, v. 56, n. 5, p. 1595-1618, 1995, p. 1595; The statutory construction analysis was subsequently applied in United States ex rel. Marcus v. Hess, 317 U.S. 537 (1943) and Rex Trailer Co., Inc. v. United States, 350 U.S. 148 (1956), among others. 


\subsection{Civil Forfeiture under the Statutory Construction Analysis: One Lot Emerald Cut Stones v. United States and United States v. One Assortment of 89 Firearms.}

In 1972 the Supreme Court handed down its decision in One Lot Emerald Cut Stones v. United States. In this case, the defendant had been tried and acquitted of charges for having entered the United States without declaring to the customs authority one lot of emerald cut stones and one ring. ${ }^{44}$ Following the criminal trial, the government brought a civil forfeiture action of the goods involved. The defendant filled a motion to dismiss on double jeopardy grounds, arguing that his previous acquittal barred the forfeiture procedure.

After recalling that Congress may impose both a criminal and a civil sanction in respect to the same conduct ${ }^{45}$ and that the question of whether a given sanction is either civil or criminal is one of statutory construction, ${ }^{46}$ the Supreme Court held that the forfeiture in question was civil and remedial. ${ }^{47}$ The Court noted that the forfeiture was intended to aid in the enforcement of tariff regulations. It prevented forbidden merchandise from circulating in the market and, by its monetary penalty, it provided a reasonable form of liquidated damages for violation of the inspection provisions and served to reimburse the Government for investigation and enforcement expenses. ${ }^{48}$ Moreover, the Court stated that the civil forfeiture brought to recover the smuggled goods was not so unreasonable or excessive that it transformed "what was clearly intended as a civil penalty into a criminal penalty". ${ }^{4}$

In 1984, the Supreme Court handed down its decision in United States v. One Assortment of 89 Firearms. In this case, the defendant was indicted and acquitted of violating the Gun Control Act by knowingly engaging in the business of dealing in firearms without a license. Following

${ }_{44}$ One Lot Emerald Cut Stones v. United States, 409 U.S. 232 (1972).
${ }_{45}$ One Lot Emerald Cut Stones v. United States, 409 U.S. 232, 235 (1972).
${ }_{46}$ One Lot Emerald Cut Stones v. United States, 409 U.S. 232, 237 (1972).
${ }_{47}$ One Lot Emerald Cut Stones v. United States, 409 U.S. 232, 237 (1972).
${ }_{48}$ One Lot Emerald Cut Stones v. United States, 409 U.S. 232, 237 (1972).
${ }_{49}$ One Lot Emerald Cut Stones v. United States, 409 U.S. 232, 237 (1972). 
the criminal acquittal, the government instituted a forfeiture action of the seized firearms. On the basis of his earlier acquittal, the defendant argued that the forfeiture procedure was barred by the double jeopardy clause. ${ }^{50}$

The Court underlined once again that, unless the forfeiture has intended as punishment, the double jeopardy clause does not applicable. ${ }^{51}$ In order to determine the nature of the forfeiture the Court applied the two-prong analysis previously developed in Ward v. United States. ${ }^{52}$

According to the ruling in Ward, the inquiry on this matter is compounded of two levels: firstly, a court should determine whether the legislature, in establishing the penalizing mechanism, indicated either expressly or impliedly that the sanction was intended to be civil in nature. Where Congress has indicated an intention to establish a civil penalty, the second step of the inquiry is to ascertain whether the statutory scheme is "so punitive either in purpose or effect as to negate that intention". ${ }^{53}$ In making this latter determination, the Court stated that the seven criteria that it had established in its decision Kennedy v. Mendoza-Martinez are useful guideposts: (i) whether the sanction involves an affirmative disability or restraint; (ii) whether it has historically been regarded as a punishment; (iii) whether it comes into play only on a finding of scienter; (iv) whether its operation will promote the traditional aims of punishment -retribution and deterrence-; (v) whether the behaviour to which it applies is already a crime; ${ }^{54}(\mathrm{vi})$ whether an alternative purpose to

50 United States v. One Assortment of 89 Firearms, 465 U.S. 354, 356 (1984).

51 United States v. One Assortment of 89 Firearms, 465 U.S. 354, 362 (1984).

52 United States v. Ward, 448 U.S. 242, 248-249 (1980); MARTIN, Janeice T. Final Jeopardy: Merging the Civil and Criminal Rounds in the Punishment Game. Florida Law Review, v. 46, n. 4, p. 661-686, 1994, p. 667; АВВOTT, Nelson T. United States v. Halper: Making Double Jeopardy Available in Civil Actions. BYU Journal of Public Law, v. 6, n. 3, p. 551-574, 1992, pp. 556-557.

53 United States v. Ward, 448 U.S. 242, 248-249 (1980); MELENYZER, Lisa. Double Jeopardy Protection from Civil Sanctions after Hudson v. United States. Journal of Criminal Law and Criminology, v. 89, n. 3, p. 1007-1046, 1999, p. 1015; MARTIN, Janeice T. Final Jeopardy: Merging the Civil and Criminal Rounds in the Punishment Game, op. cit., pp. 667-667.

${ }^{54}$ Regarding the application of this criterion, the Court cited Lipke v. Lederer, 259 U.S. 557, 562 (1922); United States v. La Franca, 282 U.S. 568, 572-573 (1931); United States v. Constantine, 296 U.S. 287, 295 (1935). 
which it may rationally be connected is assignable for it; and (vii) whether it appears excessive in relation to the alternative purpose assigned. ${ }^{55}$

Regarding the first prong of the analysis, the Court concluded that Congress designed the forfeiture in question as a remedial civil sanction. ${ }^{56}$ It noted that the civil forfeiture was not intended as punishment, but rather its purpose was to discourage unregulated commerce in firearms, keeping dangerous weapons out of the hands of unlicensed dealers. ${ }^{57}$ Concerning the second prong of the analysis, the Court observed that only one of the Kennedy criteria -whether the behaviour to which the penalty applies is already a crime- supported the position of the defendant that the forfeiture in question was a criminal penalty. However, this indication was not sufficient, since Congress may impose both a criminal and a civil sanction in respect to the same conduct. ${ }^{58}$ The Court thus concluded that the forfeiture at issue was civil in nature..$^{59}$

\subsection{The Constitutionality of Civil Forfeiture under the Excessive Fines Clause: Austin v. United States.}

Even though Austin v. United States was not a double jeopardy case, it is a cardinal case on the matter regarding the constitutionality of civil forfeiture, since the Supreme Court characterised a civil forfeiture as punishment for purposes of the excessive fines clause of the Amendment. ${ }^{60}$

In Austin, the defendant was convicted of possessing cocaine with intent to distribute and was sentenced to seven years' imprisonment.

55 Kennedy v. Mendoza-Martinez, 372 U.S. 144, 168-169 (1963); HILDY, John. Fifth Amendment--Double Jeopardy and the Dangerous Drug Tax. Journal of Criminal Law and Criminology, v. 85, n. 4, p. 936-961, 1995, p. 940.

56 United States v. One Assortment of 89 Firearms, 465 U.S. 354, 363 (1984).

57 United States v. One Assortment of 89 Firearms, 465 U.S. 354, 363-364 (1984).

58 United States v. One Assortment of 89 Firearms, 465 U.S. 354, 365 (1984).

59 United States v. One Assortment of 89 Firearms, 465 U.S. 354, 366 (1984).

60 In the same term Austin was decided, the Supreme Court handed down its decision in Alexander v. United States, where it characterised a criminal forfeiture as punishment for purposes of the excessive fines clause. See Alexander v. United States, 509 U.S. 544, 558-559 (1993). 
Subsequently, the government filed an in rem action seeking forfeiture of the mobile home and the auto body shop of the defendant. ${ }^{61}$ The District Court rejected the argument of the defendant that forfeiture of his properties would violate the excessive fines clause and granted summary judgment on the basis of an affidavit from a police officer that the defendant had brought two grams of cocaine from the mobile home to the body shop in order to consummate a prearranged sale there. The Court of Appeals upheld the decision of the District Court. ${ }^{62}$ The Supreme Court granted certiorari to resolve the question whether the forfeiture at issue constituted punishment and thus it was subjected to the Eighth Amendment. ${ }^{63}$

The Supreme Court firstly noted that unlike other provisions of the Bill of Rights, such as the self-incrimination clause of the Fifth Amendment or the protections provided by the Sixth Amendment, which are expressly confined to criminal cases, neither the text nor the history of the Eighth Amendment include such a limitation. ${ }^{64}$ The purpose of the Eighth Amendment, stated the Court, was to limit the power of the government to punish. ${ }^{65}$ Regarding the excessive fines clause, it limits the power of the government to extract payments as punishment for some offence. ${ }^{66}$ Therefore, since both civil and criminal sanctions may advance punitive as well as remedial goals, for purposes of the excessive fines clause the Court affirmed that the relevant question is not whether the forfeiture in question is civil or criminal, but rather whether it is punishment. ${ }^{67}$ The Court next analysed the historical development of

61 Austin v. United States, 509 U.S. 602, 604 (1993).

62 Austin v. United States, 509 U.S. 602, 605 (1993); WOOD, Cynthia. Asset, Forfeiture and the Excessive Fines Clause: An Epilogue to Austin v. United States. Wake Forest Law Review, v. 29, n. 4, p. 1357-1404, 1994, p. 1378.

63 Austin v. United States, 509 U.S. 602, 606 (1993).

64 Supreme Court of the United States, Austin v. United States, 607-608 [1993]; JOHNSON, Barry L. Purging the Cruel and Unusual: The Autonomous Excessive Fines Clause and Desert-Based Constitutional Limits on Forfeiture after United States v. Bajakajian, op. cit., p. 472.

65 Supreme Court of the United States, Austin v. United States, 609 [1993], citing Browning-Ferris Industries v. Kelco Disposal, 275 [1989].

66 Supreme Court of the United States, Austin v. United States, 609-610 [1993].

67 Supreme Court of the United States, Austin v. United States, 610 [1993]; GEORGE, W. David. Finally, an Eye for an Eye: The Supreme Court Lets the 
civil forfeiture, reaching the conclusion that forfeiture generally and civil forfeiture in particular historically have been understood, at least in part, as punishment. ${ }^{68}$ Regarding the forfeiture at issue, the Court found nothing to contradict this historical understanding. ${ }^{69}$ For instance, the Court noted that the forfeiture in question expressly provided an innocent owner defence, an exemption that serves to focus the inquiry on the culpability of the owner. ${ }^{70}$ Moreover, when Congress established the forfeiture up for discussion it argued that traditional criminal sanctions had been inadequate to deter and punish the enormously profitable trade in dangerous drugs, hence additional measures were necessary. ${ }^{71}$

Considering the historical understanding of forfeiture as punishment, the clear focus of the forfeiture at stake on the culpability of the owner and the evidence that Congress understood it as serving to deter and punish, the Supreme Court held that the forfeiture in question constituted punishment for purposes of the excessive fines clause. ${ }^{72}$ Nevertheless, the Supreme Court refused the invitation of the defendant to establish a multifactor test for determining whether a forfeiture is constitutionally excessive. The Court argued that prudence dictated to

Punishment Fit the Crime in Austin v. United States. Baylor Law Review, v. 46, n. 2, p. 509-524, 1994, p. 515; SUBIN, Andrew L. The Double Jeopardy Implications of In Rem Forfeiture of Crime-Related Property: The Gradual Realization of a Constitutional Violation, op. cit., p. 261.

Austin v. United States, 509 U.S. 602, 618 (1993); HENNING, Peter J. Precedents in a Vacuum: The Supreme Court Continues to Tinker with Double Jeopardy, op. cit., p. 65; SACKETT, Robin M. The Impact of Austin v. United States: Extending Constitutional Protections to Claimants in Civil Forfeiture Proceedings. Golden Gate University Law Review, v. 24, n. 2, p. 495-522, 1994 , p. 509; WOOD, Cynthia. Asset, Forfeiture and the Excessive Fines Clause: An Epilogue to Austin v. United States, op. cit., p. 1379.

69 SACKETT, Robin M. The Impact of Austin v. United States: Extending Constitutional Protections to Claimants in Civil Forfeiture Proceedings, op. cit., p. 510. Austin v. United States, 509 U.S. 602, 619 (1993).

71 Austin v. United States, 509 U.S. 602, 620 (1993); GEORGE, W. David. Finally, an Eye for an Eye: The Supreme Court Lets the Punishment Fit the Crime in Austin v. United States, op. cit., p. 515.

72 Austin v. United States, 509 U.S. 602, 621-622 (1993); HENNING, Peter J. Precedents in a Vacuum: The Supreme Court Continues to Tinker with Double Jeopardy, op. cit., p. 18. 
allow the lower courts to consider that question in the first instance. ${ }^{73}$ Therefore, the Supreme Court reversed the judgment of the Court of Appeals and remanded the case for a determination of proportionality. ${ }^{74}$

\subsection{Reversing the Direction: United States v. Ursery.}

After Austin v. United States there was great expectancy for knowing the next decision of the Supreme Court on the constitutionality of civil forfeiture. The subsequent decision delivered by the Court on this matter was United States v. Ursery, a case in which the Court held that a civil forfeiture did not constitute punishment for double jeopardy purposes, reversing thereby the direction of the development of the case law. ${ }^{75}$

In Ursery, the Court consolidated two cases to determine whether a civil forfeiture in addition to a criminal prosecution for the same offence violated the double jeopardy clause. ${ }^{76}$ In the first case, the police discovered a marijuana manufacturing operation in the home of the defendant, Guy Ursery. The government instituted a civil forfeiture proceeding to recoup the residence because it was used in the manufacturing operation. The defendant settled the forfeiture suit by paying the federal government $\$ 13,250.167$. Subsequently, the defendant was indicted and convicted of manufacturing marijuana. ${ }^{77}$ The defendant appealed his criminal conviction, arguing that the criminal penalty constituted a second

\footnotetext{
73 Supreme Court of the United States, Austin v. United States, 622-623 [1993]; REINHART, Douglas. Applying the Eighth Amendment to Civil Forfeiture After Austin v. United States: Excessiveness and Proportionality, op. cit., p. 243. Supreme Court of the United States, Austin v. United States, 623 [1993].

MELENYZER, Lisa. Double Jeopardy Protection from Civil Sanctions after Hudson v. United States, op. cit., 1021; SOLOMON, Matthew C. The Perils of Minimalism: United States v. Bajakajian in the Wake of the Supreme Court's Civil Double Jeopardy Excursion Note, op. cit., p. 864.

76 WATKINS, Amy E. Double Jeopardy Clause - Government May Bring Parallel Criminal Prosecution and In Rem Forfeiture Actions without Violating the Double Jeopardy Clause Survey: Fifth Amendment. Seton Hall Constitutional Law Journal, v. 7, n. 1, 287-292, 1996, p. 287.

United States v. Ursery, 518 U.S. 267, 271 (1996).
} 
impermissible punishment in violation of the double jeopardy clause. ${ }^{78}$ In the second case, United States v. \$405,089.23 in U. S. Currency et al., the defendants were convicted of conspiracy to aid and abet the manufacture of methamphetamine, conspiracy to launder monetary instruments, and numerous counts of money laundering. ${ }^{79}$ The government also instituted a contemporaneous civil forfeiture proceeding against property owned by the defendants that was used in their illegal operations. ${ }^{80}$ After the conclusion of the criminal procedure, the District Court granted the motion of the government for summary judgment in the forfeiture proceeding. The defendants appealed the decision on double jeopardy grounds. ${ }^{81}$ In both cases, Ursery and $\$ 405,089.23$, the Supreme Court granted certiorari and held a civil forfeiture may be brought in conjunction with a criminal trial without violating the double jeopardy clause. ${ }^{82}$

The Supreme Court firstly highlighted that in a long line of cases, composed of Various Items of Personal Property et al., One Lot Emerald Cut Stones and One Assortment of 89 Firearms, ${ }^{83}$ it had consistently concluded that in rem civil forfeiture is a remedial civil sanction and therefore does not constitute punishment for double jeopardy purposes. ${ }^{84}$ The Court then noted that none of its previous decisions had overruled the well-established teaching of Various Items, Emerald Cut Stones, and 89 Firearms. ${ }^{85}$ Moreover, the Court remarked that while Austin had

78 VINES, J. Andrew. United States v. Ursery: The Supreme Court Refuses to Extend Double Jeopardy Protection to Civil in Rem Forfeiture. Arkansas Law Review, v. 50, n. 4, p. 797-840, 1997, p. 803.

79 United States v. Ursery, 518 U.S. 267, 271 (1996). NOLAN, Patrick S. Double Jeopardy's Multipunishment Protection and Regulation of Civil Sanctions after United States v. Ursery, op. cit., p. 1101. United States v. Ursery, 518 U.S. 267, 272 (1996). WATKINS, Amy E. Double Jeopardy Clause - Government May Bring Parallel Criminal Prosecution and In Rem Forfeiture Actions without Violating the Double Jeopardy Clause Survey: Fifth Amendment, op. cit., p. 288. United States v. Ursery, 518 U.S. 267, 274-278 (1996). United States v. Ursery, 518 U.S. 267, 278 (1996); VINES, J. Andrew. United States v. Ursery: The Supreme Court Refuses to Extend Double Jeopardy Protection to Civil in Rem Forfeiture, op. cit., p. 825. United States v. Ursery, 518 U.S. 267, 282 (1996); VINES, J. Andrew. United States v. Ursery: The Supreme Court Refuses to Extend Double Jeopardy 
dealt with the question whether civil forfeiture constitutes punishment for purposes of the excessive fines clause, Ursery deals with another issue: whether civil forfeiture constitutes punishment for purposes of the double jeopardy clause. ${ }^{86}$

Afterwards, the Supreme Court examined the forfeitures in question under the two-prong analysis of Ward.$^{87}$ Regarding the first part of the analysis, the Supreme Court found several characteristics that supported the conclusion that Congress had intended these forfeitures to be civil in nature.$^{88}$ For instance, the Court noted that forfeitures at issue were in rem, just like customs laws forfeitures, ${ }^{89}$ being structured to be impersonal by targeting the property itself. ${ }^{90}$ Moreover, the Court observed that "actual notice of the impending forfeiture is unnecessary when the Government cannot identify any party with an interest in the seized article". ${ }^{91}$ Moving to the second step of the analysis, the Supreme Court found little evidence suggesting that the forfeitures in question were so punitive either in form or effect as to render them criminal despite the intent of Congress. The Court noted that the civil forfeiture at stake served important non-punitive goals, such as guaranteeing that persons do not profit from their illegal acts, or encouraging property owners to take care in managing their property, ensuring that they will not permit that property to be used in illegal activities. ${ }^{92}$ In addition, the Court remarked that forfeitures at issue did not require proving scienter. ${ }^{93}$

\footnotetext{
Protection to Civil in Rem Forfeiture, op. cit., p. 825.

86 United States v. Ursery, 518 U.S. 267, 288 (1996).

87 United States v. Ursery, 518 U.S. 267, 288 (1996); VINES, J. Andrew. United States v. Ursery: The Supreme Court Refuses to Extend Double Jeopardy Protection to Civil in Rem Forfeiture, op. cit., p. 825; MELENYZER, Lisa. Double Jeopardy Protection from Civil Sanctions after Hudson v. United States, op. cit., p. 1022.

United States v. Ursery, 518 U.S. 267, 288 (1996).

United States v. Ursery, 518 U.S. 267, 288-289 (1996).

United States v. Ursery, 518 U.S. 267, 289 (1996).

United States v. Ursery, 518 U.S. 267, 289 (1996).

United States v. Ursery, 518 U.S. 267, 290-291 (1996).

United States v. Ursery, 518 U.S. 267, 291 (1996).
} 
Accordingly, the Supreme Court ruled that civil forfeiture does not constitute criminal punishment for double jeopardy purposes. ${ }^{94}$ Consequently, the double jeopardy clause does not bar the imposition of both a criminal penalty and a civil forfeiture for the same conduct. ${ }^{95}$

\section{Recalling the Excessive Fines Clause}

The current state of the case law of the Supreme Court on the constitutionality of parallel civil forfeiture proceedings and criminal prosecutions under the double jeopardy clause is that civil forfeiture does not constitute criminal punishment for double jeopardy purposes. Thus, the Fifth Amendment does not preclude the government from bringing parallel civil forfeiture proceedings and criminal prosecutions for the same offence.

Nevertheless, Ursery neither overruled nor modified the ruling in Austin v. United States. Therefore, even though the double jeopardy clause does not prevent the government from bringing parallel civil forfeiture proceeding and criminal prosecutions for the same offence, civil forfeiture is still limited by the excessive fines clause of the Eighth Amendment, ${ }^{96}$ which provides: "Excessive bail shall not be required, nor excessive fines imposed, nor cruel and unusual punishments inflicted".

The Eighth Amendment was adopted in 1791, directly from the English Bill of Rights of $1689 .{ }^{97}$ The history indicates that the framers intended the entire amendment to act as a limit on the power of the

94 United States v. Ursery, 518 U.S. 267, 270-271 (1996); WELLS, Adam C. Multiple-Punishment and the Double Jeopardy Clause: The United States v. Ursery Decision, op. cit., p. 161; NELSON, Caleb. The Constitutionality of Civil Forfeiture, op. cit., p. 2491.

95 NOLAN, Patrick S. Double Jeopardy's Multipunishment Protection and Regulation of Civil Sanctions after United States v. Ursery, op. cit., p. 1111.

96 PIMENTEL, David. Forfeitures and the Eighth Amendment: A Practical Approach to the Excessive Fines Clause as a Check on Government Seizures, op. cit., p. 555.

97 GRANUCCI Anthony. Nor Cruel and Unusual Punishments Inflicted: The Original Meaning. California Law Review, v. 57, n. 4, p. 839-865, 1969, p. 840. 
government to punish. ${ }^{98}$ The Eighth Amendment contains three different prohibitions: a prohibition of excessive bail, a prohibition of cruel and unusual punishments, which is concerned with matters such as the duration or conditions of confinement, and a prohibition of excessive fines, which limits the power of the government to extract payments as punishment for some offence. ${ }^{99}$ The Supreme Court has recently underlined that the excessive fines clause is an incorporated protection applicable to the States under the due process clause of the Fourteenth Amendment. ${ }^{100}$

Prior to Austin, the Supreme Court had only considered the excessive fines clause in Browning-Ferris Industries v. Kelco Disposal. In this case, the Supreme Court held that the excessive fines clause does not apply to disputes between private parties, stating that the excessive fines clause "was intended to limit only those fines directly imposed by, and payable to, the government". ${ }^{101}$

Despite the importance of the ruling in Austin that the excessive fines clause applies to civil forfeiture, the Court declined to establish a test

98 Accordingly, Reinhart states that analysis under the excessive fines clause should be similar to that required by the cruel and unusual punishments clause and the excessive bail clause. REINHART, Douglas. Applying the Eighth Amendment to Civil Forfeiture After Austin v. United States: Excessiveness and Proportionality, op. cit., pp. 252-253.

99 Alexander v. United States, 509 U.S. 544, 558 (1993); ALBIN, Laurel. Notes: Constitutional Limitations of Civil in Rem Forfeiture and the Double Jeopardy Dilemma: Civil in Rem Forfeiture Constitutes Punishment and Is Subject to Excessive Fines Analysis. Aravanis v. Somerset County, 339 Md. 644, 664 A.2d 888 (1995), Cert. Denied, 116 S. Ct. 916 (1996), op. cit., p. 156. See also Browning-Ferris Industries v. Kelco Disposal, 492 U.S. 257, 265 (1989); Austin v. United States, 509 U.S. 602, 609-610 (1993); United States v. Bajakajian, 524 U.S. 321, 328 (1998).

100 Timbs v. Indiana, 586 U.S., 7 (2019).

${ }^{101}$ Browning-Ferris Industries v. Kelco Disposal, 492 U.S. 257, 268 (1989); GEORGE, W. David. Finally, an Eye for an Eye: The Supreme Court Lets the Punishment Fit the Crime in Austin v. United States, op. cit., p. 515; ALBIN, Laurel. Notes: Constitutional Limitations of Civil in Rem Forfeiture and the Double Jeopardy Dilemma: Civil in Rem Forfeiture Constitutes Punishment and Is Subject to Excessive Fines Analysis. Aravanis v. Somerset County, 339 Md. 644, 664 A.2d 888 (1995), Cert. Denied, 116 S. Ct. 916 (1996), op. cit., p. 166; SOLOMON, Matthew C. The Perils of Minimalism: United States v. Bajakajian in the Wake of the Supreme Court's Civil Double Jeopardy Excursion Note, op. cit., p. 871. 
for determining excessiveness in this specific context. ${ }^{102}$ Due to the lack of direction given by the Supreme Court in Austin, lower courts developed their own tests, which tend to emphasize either an "instrumentality" or a "proportionality" approach. ${ }^{103}$ Under the first test, the relevant question is whether there is a close enough relationship between the property and the offence to render the property, under traditional standards, guilty and hence forfeitable. ${ }^{104}$ On the contrary, the proportionality test utilises the criteria established by the Supreme Court with regard to the other prohibitions contained in the Eighth Amendment. Recognising that the Eight Amendment establishes parallel limitations on bail, fines and other punishments, ${ }^{105}$ lower courts have applied the analysis of the Supreme Court on the excessive bail and cruel and unusual punishments clauses to the excessive fines clause. ${ }^{106}$

\subsection{United States v. Bajakajian and the Proportionality Approach.}

Notwithstanding the lack of consensus among lower courts, the Supreme Court did not clarify its excessive fines clause case law until 1998,

102 ALBIN, Laurel. Notes: Constitutional Limitations of Civil in Rem Forfeiture and the Double Jeopardy Dilemma: Civil in Rem Forfeiture Constitutes Punishment and Is Subject to Excessive Fines Analysis. Aravanis v. Somerset County, 339 Md. 644, 664 A.2d 888 (1995), Cert. Denied, 116 S. Ct. 916 (1996), op. cit., p. 167; LIEBER, David. Eighth Amendment--The Excessive Fines Clause. Journal of Criminal Law and Criminology, v. 84, n. 4, p. 805-826, 1994, p. 823.

103 JOHNSON, Barry L. Purging the Cruel and Unusual: The Autonomous Excessive Fines Clause and Desert-Based Constitutional Limits on Forfeiture after United States v. Bajakajian, op. cit., p. 474.

${ }^{104}$ The instrumentality test was announced by Justice Scalia in its concurring opinion in Austin. See Austin v. United States, 509 U.S. 602, 628 (Scalia, J., concurring) (1993).

105 Solem v. Helm. 463 U.S. 277, 289 (1983). See also Timbs v. Indiana, 586 U.S. 3 (2019)

106 ALBIN, Laurel. Notes: Constitutional Limitations of Civil in Rem Forfeiture and the Double Jeopardy Dilemma: Civil in Rem Forfeiture Constitutes Punishment and Is Subject to Excessive Fines Analysis. Aravanis v. Somerset County, 339 Md. 644, 664 A.2d 888 (1995), Cert. Denied, 116 S. Ct. 916 (1996), op. cit., p. 173; JOHNSON, Barry L. Purging the Cruel and Unusual: The Autonomous Excessive Fines Clause and Desert-Based Constitutional Limits on Forfeiture after United States v. Bajakajian, op. cit., pp. 476-478. 
when it delivered its decision in United States v. Bajakajian, ${ }^{107}$ declaring disproportionate the criminal forfeiture sought by the government under the excessive fines clause. ${ }^{108}$

In Bajakajian, respondent and his family were waiting at Los Angeles International Airport to board a flight abroad. A customs inspector approached respondent and his wife and told them that they were required to report all money in excess of $\$ 10,000$. Respondent said that he had $\$ 8,000$ and that his wife had another $\$ 7,000$, but that the family had no additional currency to declare. A search of their baggage and personal bags revealed a total of $\$ 357,144$. The currency was seized and respondent was taken into custody. ${ }^{109}$ The respondent was indicted with failing to report that he was transporting more than $\$ 10,000$ outside the United States. The defendant pleaded guilty to the failure to report and was convicted. The government sought forfeiture of the $\$ 357,144$ pursuant to 18 U. S. C. $\S 982(\mathrm{a})(1)$, which provides that the court, in imposing sentence on a person convicted for the previous offence, shall order the forfeiture of any property involved in such offence, or any property traceable to such property. ${ }^{110}$ Respondent elected to have a bench trial on the forfeiture. After the bench trial, the trial court found that the entire $\$ 357,144$ was subject to forfeiture because it was "involved in" the offence. ${ }^{111}$ The court also found that "the funds were not connected to any other crime and that respondent was transporting the money to repay a lawful debt". ${ }^{112}$ Even though the relevant statute provided to impose full forfeiture of the property involved in the offence, the court concluded that such forfeiture would be extraordinarily harsh and grossly disproportionate to the offence in

107 JOHNSON, Barry L. Purging the Cruel and Unusual: The Autonomous Excessive Fines Clause and Desert-Based Constitutional Limits on Forfeiture after United States v. Bajakajian, op. cit., p. 478

108 SOLOMON, Matthew C. The Perils of Minimalism: United States v. Bajakajian in the Wake of the Supreme Court's Civil Double Jeopardy Excursion Note, op. cit., p. 849.

${ }^{109}$ United States v. Bajakajian, 524 U.S. 321, 324-325 (1998).

${ }^{110}$ United States v. Bajakajian, 524 U.S. 321, 325 (1998).

${ }^{111}$ United States v. Bajakajian, 524 U.S. 321, 325-326 (1998).

${ }^{112}$ United States v. Bajakajian, 524 U.S. 321, 326 (1998). 
question, violating thereby the excessive fines clause. The court instead ordered forfeiture of $\$ 15,000$, in addition to a sentence of three years of probation and a fine of $\$ 5,000$. The government appealed, seeking full forfeiture of the seized currency. The Court of Appeal for the Ninth Circuit affirmed. ${ }^{113}$ Because the judgment of the Court of Appeal invalidated a part of an Act of Congress, the Supreme Court granted certiorari. ${ }^{114}$

The Supreme Court effortlessly concluded that the forfeiture at stake constituted punishment. The Court noted that the forfeiture in question was imposed as an additional sanction on a person convicted of an offence at the culmination of a criminal proceeding. Accordingly, the imposition of the forfeiture at issue required a conviction of an underlying offence, not being possible imposing it on an innocent owner. ${ }^{115}$

After holding that the forfeiture of the currency constituted punishment and that therefore the excessive fines clause was applicable, the Supreme Court turned to the question whether the forfeiture was excessive. In this regard, the Court held that the touchstone of the constitutional inquiry under the excessive fines clause is the principle of proportionality. Since the amount of the forfeiture must bear some relationship to the gravity of the offence committed by the defendant, the Supreme Court ruled that a punitive forfeiture violates the excessive fines clause when it is "grossly disproportionate" to the gravity of the offence. ${ }^{116}$ If the amount of the forfeiture is grossly disproportionate to the gravity of the offence committed by the defendant, the forfeiture will be contrary to the Eighth Amendment. ${ }^{117}$

\footnotetext{
113 United States v. Bajakajian, 524 U.S. 321, 326 (1998).

${ }^{114}$ United States v. Bajakajian, 524 U.S. 321, 327 (1998).

115 United States v. Bajakajian, 524 U.S. 321, 328 (1998); JOHNSON, Barry L. Purging the Cruel and Unusual: The Autonomous Excessive Fines Clause and Desert-Based Constitutional Limits on Forfeiture after United States v. Bajakajian, op. cit., pp. 480-482.

116 United States v. Bajakajian, 524 U.S. 321, 334 (1998); PIMENTEL, David. Forfeitures and the Eighth Amendment: A Practical Approach to the Excessive Fines Clause as a Check on Government Seizures, op. cit., p. 559; BENNARDO, Kevin. Restitution and the Excessive Fines Clause. Louisiana Law Review, v. 77, n. 1, p. 21-45, 2016, p. 32.

117 United States v. Bajakajian, 524 U.S. 321, 337 (1998); JOHNSON, Barry L. Purging the Cruel and Unusual: The Autonomous Excessive Fines Clause and
} 
Applying the gross disproportionality standard, the Supreme Court considered that the offence committed by the defendant was solely a reporting offence, whose essence was a failure to report the removal of currency from the United States ${ }^{118}$ and that the violation was unrelated to any other illegal activities. Therefore, the conduct of the defendant did not fit into the class of persons for whom the statute was principally designed: he was not a money launderer, a drug trafficker, or a tax evader. ${ }^{119}$ Moreover, the Court noted that the harm that respondent caused was minimal, there had not been fraud in the United States and the failure to report his currency affected only the government. ${ }^{120}$

For the foregoing reasons, the Supreme Court concluded that the forfeiture of $\$ 357,144$ sought by the government would be grossly disproportionate to the gravity of the offence committed by the defendant, violating thereby the excessive fines clause. ${ }^{121}$ The Supreme Court upheld the $\$ 15,000$ forfeiture imposed by the district court. ${ }^{122}$

\subsection{Analysing the Decision in Bajakajian.}

The decision of the Supreme Court in United States v. Bajakajian, holding that the right approach in the context of the excessive fines clause is the proportionality standard, has two main merits.

The first merit of the decision is having allowed to overcome the situation of uncertainty in lower courts, which were divided between the proportionality standard and the instrumentality approach. ${ }^{123}$ By embracing the former approach the Court firmly rejected the latter one.

Desert-Based Constitutional Limits on Forfeiture after United States v. Bajakajian, op. cit., pp. 482-483.

118 United States v. Bajakajian, 524 U.S. 321, 337 (1998).

${ }^{119}$ United States v. Bajakajian, 524 U.S. 321, 338 (1998).

${ }^{120}$ United States v. Bajakajian, 524 U.S. 321, 339 (1998).

${ }^{121}$ United States v. Bajakajian, 524 U.S. 321, 339-340 (1998).

${ }^{122}$ United States v. Bajakajian, 524 U.S. 321, 339-340 (1998).

${ }^{123}$ JOHNSON, Barry L. Purging the Cruel and Unusual: The Autonomous Excessive Fines Clause and Desert-Based Constitutional Limits on Forfeiture after United States v. Bajakajian, op. cit., pp. 486. 
The second merit of the decision is having strengthened the proportionality approach by making it applicable outside the cruel and unusual punishments clause. As the same Supreme Court recognised, the gross disproportionality standard was originally articulated in its case law on the cruel and unusual punishments clause. ${ }^{124}$ In Solem v. Helm, decided in 1983, the Supreme Court held a straightforward idea: "a criminal sentence must be proportionate to the crime for which the defendant has been convicted". ${ }^{125}$ The prohibition of imposing "grossly disproportional" punishments and fines is a current standard of the Supreme Court constitutional case law. In Ewing v. California, decided in 2003, the defendant, while on parole, was convicted of felony grand theft for stealing three golf clubs, worth $\$ 399$ apiece. Because the defendant had been previously convicted of four serious or violent felonies, the prosecutor alleged and the trial court applied the California's three strikes law, sentencing him to 25 years to life. The Supreme Court stated that the Eighth Amendment contains a "narrow proportionality principle", which only forbids extreme sentences that are "grossly disproportionate" to the crime. ${ }^{126}$ Regarding the case in question, the Court concluded that the sentence of 25 years to life in prison, imposed on the defendant for the offense of felony grand theft under the three strikes law was not grossly disproportionate, therefore there was no violation of the Eighth Amendment. ${ }^{127}$

Notwithstanding the significance of the decision in Bajakajian, there is one problematic issue that should be critically addressed: the threshold of the gross disproportionality standard.

Besides the standard does not provide clear guidelines to lower courts in the application of the excessive fines clause, ${ }^{128}$ the main problem of the standard itself is the demanding threshold that the Supreme Court has established. As the Supreme Court recognised in

\footnotetext{
${ }^{124}$ United States v. Bajakajian, 524 U.S. 321, 336 (1998).

125 Solem v. Helm. 463 U.S. 277, 290 (1983).

${ }^{126}$ Ewing v. California, 538 U.S. 11, 20 (2003). See also Lockyer v. Andrade, 538 U.S. 63, 72 (2003).

127 Ewing v. California, 538 U.S. 11, 30 (2003).

128 PIMENTEL, David. Forfeitures and the Eighth Amendment: A Practical Approach to the Excessive Fines Clause as a Check on Government Seizures, op. cit., p. 561 .
} 
Bajakajian, the gross disproportionality standard was borrowed from the case law on the cruel and unusual punishments clause. In the context of the prohibition of cruel and unusual punishments, the extreme deference to legislative sentencing determinations represented by the demanding threshold of "grossly" has been firstly explained on the basis of the wording of the prohibition itself: "cruel and unusual". ${ }^{129}$ For instance, in Harmelin v. Michigan the Supreme Court held that severe mandatory penalties "may be cruel, but they are not unusual in the constitutional sense, having being employed in various forms throughout our Nation's history". ${ }^{130}$ The extreme deference to legislature on this topic was explained by the Supreme Court in Rummel v. Estelle, where after noting that outside the context of capital punishment successful challenges to disproportional sentences have been exceedingly rare, the Court held that the length of terms of imprisonment is mainly a matter of legislative prerogative. ${ }^{131}$

Since the language of the excessive fines clause is not similar at all to the prohibition of cruel and unusual punishments, the arguments to justify the gross disproportionality standard in the former guarantee are significantly weaker. ${ }^{132}$ Although it could seem obvious, the excessive fines clause does not refer to grossly excessive fines, but rather it mentions excessive fines. Therefore, it seems reasonable to state that due to the different wording contained in the Eighth Amendment the threshold in the context of the excessive fines clause should be diverse from the threshold of the cruel and unusual punishments clause. It could certainly be argued that this sole difference of wording between the two constitutional prohibitions is not a conclusive argument in order to exclude the gross disproportionality standard from the scope of application of the excessive fines clause. However, this difference should at least be considered and

${ }^{129}$ JOHNSON, Barry L. Purging the Cruel and Unusual: The Autonomous Excessive Fines Clause and Desert-Based Constitutional Limits on Forfeiture after United States v. Bajakajian, op. cit., p. 487.

${ }^{130}$ Harmelin v. Michigan, 501 U.S. 957, 994-995 (1991).

${ }^{131}$ Rummel v. Estelle, 445 U.S. 263, 274 (1980).

${ }^{132}$ JOHNSON, Barry L. Purging the Cruel and Unusual: The Autonomous Excessive Fines Clause and Desert-Based Constitutional Limits on Forfeiture after United States v. Bajakajian, op. cit., p. 487. 
explained before concluding that for applying both the cruel and unusual punishments clause and the excessive fines clause it is required the same threshold. On this matter, the Supreme Court seems to have just imported the standard at stake from one clause to another.

\section{Conclusions.}

Does the double jeopardy clause of the Fifth Amendment to the United States Constitution precludes the government from bringing parallel civil forfeiture proceedings and criminal prosecutions for the same offence?

According to the Supreme Court, the answer is no. The reasoning of the Court was set out in United States v. Ursery: because the double jeopardy clause only applies to criminal cases, and since civil forfeiture is civil in nature under the two-prong analysis developed in Ward, the double jeopardy clause does not apply to this law enforcement mechanism. Considering that after Ursery the Supreme Court has not granted a writ of certiorari regarding the constitutionality of parallel civil forfeiture proceedings and criminal prosecutions under the double jeopardy clause, the Court is unlikely to change its interpretation. The discussion about this specific matter, thus, would be concluded.

The foregoing assertion does not mean, however, that parallel civil forfeiture proceedings and criminal prosecutions do not have constitutional limitations. Indeed, the same Supreme Court has noted that some of the ills that have been tried to be solved applying the double jeopardy clause are addressed by other constitutional provisions. In the case of civil forfeiture, the Supreme Court held in Austin v. United States that they are limited by the excessive fines clause of the Eighth Amendment. The relevant question is, therefore, whether the civil forfeiture in question is "grossly disproportionate" to the gravity of the offence committed by the defendant. If so, the forfeiture will be contrary to the Eighth Amendment.

Developing more accurate criteria and guidelines to ascertain when a forfeiture is grossly disproportionate is the road that scholars and courts should follow. 


\section{BibliogRAPHY}

ABBOTT, Nelson T. United States v. Halper: Making Double Jeopardy Available in Civil Actions. BYU Journal of Public Law, v. 6, n. 3, p. 551-574, 1992.

ALBIN, Laurel. Notes: Constitutional Limitations of Civil in Rem Forfeiture and the Double Jeopardy Dilemma: Civil in Rem Forfeiture Constitutes Punishment and Is Subject to Excessive Fines Analysis. Aravanis v. Somerset County, 339 Md. 644, 664 A.2d 888 (1995), Cert. Denied, 116 S. Ct. 916 (1996). University of Baltimore Law Review, v. 26, n. 1, p. 155-199, 1996.

AMAR, Akhil, and Jonathan L. Marcus. Double Jeopardy Law after Rodney King. Columbia Law Review, v. 95, n. 1, p. 1-59, 1995.

ANIELAK, Eric Michael. Double Jeopardy: Protection against Multiple Punishments. Missouri Law Review, v. 61, n. 1, p. 169-184, 1996.

BATRA, Rishi. Resolving Civil Forfeiture Disputes. University of Kansas Law Review, v. 66, n. 2, p. 399-426, 2017.

BENNARDO, Kevin. Restitution and the Excessive Fines Clause. Louisiana Law Review, v. 77, n. 1, p. 21-45, 2016.

CARLTON, Christopher W. Cumulative Sentences for One Criminal Transaction Under the Double Jeopardy Clause: Whalen v. United States. Cornell Law Review, v. 66, n. 4, p. 819-841, 1981.

CLERMONT, Kevin M. Procedure's Magical Number Three Psychological Bases for Standards of Decision. Cornell Law Review, v. 72, n. 6, p. 1115-1156, 1987.

COLGAN, Beth A. The Excessive Fines Clause: Challenging the Modern Debtors' Prison. UCLA Law Review, v. 65, n. 1, p. 2-77, 2018.

GEORGE, W. David. Finally, an Eye for an Eye: The Supreme Court Lets the Punishment Fit the Crime in Austin v. United States. Baylor Law Review, v. 46, n. 2, p. 509-524, 1994.

GRANUCCI, Anthony. Nor Cruel and Unusual Punishments Inflicted: The Original Meaning. California Law Review, v. 57, n. 4, p. 839-865, 1969.

HENNING, Peter J. Precedents in a Vacuum: The Supreme Court Continues to Tinker with Double Jeopardy. American Criminal Law Review, v. 31, n. 1, p. 1-72, 1993.

HILDY, John. Fifth Amendment--Double Jeopardy and the Dangerous Drug Tax. Journal of Criminal Law and Criminology, v. 85, n. 4, p. 936-961, 1995. 
JAMES, Fleming. Burdens of Proof. Virginia Law Review, v. 47, n. 1, p. 51-70, 1961.

JOHNSON, Barry L. Purging the Cruel and Unusual: The Autonomous Excessive Fines Clause and Desert-Based Constitutional Limits on Forfeiture after United States v. Bajakajian. University of Illinois Law Review, n. 2, p. 461-516, 2000.

KLEIN, Susan R. Civil in Rem Forfeiture and Double Jeopardy. Iowa Law Review, v. 82, n. 1, p. 183-274, 1996.

LIEBER, David. Eighth Amendment--The Excessive Fines Clause. Journal of Criminal Law and Criminology, v. 84, n. 4, p. 805-826, 1994.

LIMBAUGH, Stephen. The Case of Ex Parte Lange (Or How the Double Jeopardy Clause Lost Its Life or Limb). American Criminal Law Review, v. 36, n. 1, p. 53$86,1999$.

MARTIN, Janeice T. Final Jeopardy: Merging the Civil and Criminal Rounds in the Punishment Game. Florida Law Review, v. 46, n. 4, p. 661-686, 1994.

MELENYZER, Lisa. Double Jeopardy Protection from Civil Sanctions after Hudson v. United States. Journal of Criminal Law and Criminology, v. 89, n. 3, p. 10071046, 1999.

MERKL, Taryn A. The Federalization of Criminal Law and Double Jeopardy. Columbia Human Rights Law Review, v. 31, n. 1, p. 175-208, 1999.

NELSON, Caleb. The Constitutionality of Civil Forfeiture. Yale Law Journal, v. 125, n. 8, p. 2446-2518, 2016.

NOLAN, Patrick S. Double Jeopardy's Multipunishment Protection and Regulation of Civil Sanctions after United States v. Ursery. Marquette Law Review, v. 80, n. 4, p. 1081-1116, 1997.

PIMENTEL, David. Forfeitures and the Eighth Amendment: A Practical Approach to the Excessive Fines Clause as a Check on Government Seizures. Harvard Law \& Policy Review, v. 11, n. 2, p. 541-584, 2017.

REINHART, Douglas. Applying the Eighth Amendment to Civil Forfeiture After Austin v. United States: Excessiveness and Proportionality. William \& Mary Law Review, v. 36, n. 1, p. 235-268, 1994.

RUDSTEIN, David. Double Jeopardy: A Reference Guide to the United States Constitution. Praeger, 2004.

SACKETT, Robin M. The Impact of Austin v. United States: Extending Constitutional Protections to Claimants in Civil Forfeiture Proceedings. Golden Gate University Law Review, v. 24, n. 2, p. 495-522, 1994. 
SCHWARTZ, David L., and SEAMAN, Christopher B. Standards of Proof in Civil Litigation: An Experiment from Patent Law. Harvard Journal of Law \& Technology, v. 26, n. 2, p. 429-480, 2013.

SIGLER, Jay A. Federal Double Jeopardy Policy. Vanderbilt Law Review, v. 19, n. 2, p. 375-405, 1966.

SOLOMON, Matthew C. The Perils of Minimalism: United States v. Bajakajian in the Wake of the Supreme Court's Civil Double Jeopardy Excursion Note. Georgetown Law Journal, v. 87, n. 3, 849-886, 1999.

SUBIN, Andrew L. The Double Jeopardy Implications of In Rem Forfeiture of Crime-Related Property: The Gradual Realization of a Constitutional Violation. Seattle University Law Review, v. 19, n. 2, p. 253-288, 1996.

SUMMERS, Brian L. Double Jeopardy: Rethinking the Parameters of the Multiplicity Prohibition. Ohio State Law Journal, v. 56, n. 5, p. 1595-1618, 1995.

TAIFA, Nkechi. Civil Forfeiture vs. Civil Liberties. New York Law School Law Review, v. 39, n. 1-2, p. 95-120, 1994.

VINES, J. Andrew. United States v. Ursery: The Supreme Court Refuses to Extend Double Jeopardy Protection to Civil in Rem Forfeiture. Arkansas Law Review, v. 50, n. 4, p. 797-840, 1997.

WATKINS, Amy E. Double Jeopardy Clause - Government May Bring Parallel Criminal Prosecution and In Rem Forfeiture Actions without Violating the Double Jeopardy Clause Survey: Fifth Amendment. Seton Hall Constitutional Law Journal, v. 7, n. 1, 287-292, 1996.

WELLS, Adam C. Multiple-Punishment and the Double Jeopardy Clause: The United States v. Ursery Decision. St. John's Law Review, v. 71, n. 1, p. 153-172, 1997. WOOD, Cynthia. Asset, Forfeiture and the Excessive Fines Clause: An Epilogue to Austin v. United States. Wake Forest Law Review, v. 29, n. 4, p. 1357-1404, 1994.

\section{TABle of CASEs}

Ex parte Lange, 85 U.S. 163 (1873).

Goldsmith-Grant Co. v. United States, 254 U.S. 505, 511 (1921).

Lipke v. Lederer, 259 U.S. 557 (1922).

United States v. La Franca, 282 U.S. 568 (1931). 
Various Items of Personal Property et al. v. United States, 282 U.S. 577 (1931).

United States v. Benz, 282 U.S. 304 (1931).

Blockburger v. United States, 284 U.S. 299 (1932).

United States v. Constantine, 296 U.S. 287 (1935).

Helvering v. Mitchell, 303 U.S. 391 (1938).

United States ex rel. Marcus v. Hess, 317 U.S. 537 (1943).

Rex Trailer Co., Inc. v. United States, 350 U.S. 148 (1956).

Green v. United States, 355 U.S. 184 (1957).

Kennedy v. Mendoza-Martinez, 372 U.S. 144 (1963).

North Carolina v. Pearce, 395 U.S. 711 (1969).

Benton v. Maryland, 395 U.S. 784 (1969).

United States v. Wilson, 420 U.S. 332 (1975).

United States v. Jenkins, 420 U.S. 358 (1975).

Iannelli v. United States, 420 U.S. 770 (1975).

Brown v. Ohio, 432 U.S. 161 (1977).

Burks v. United States, 437 U.S. 1 (1978).

United States v. Ward, 448 U.S. 242 (1980).

United States v. Di Francesco, 449 U.S. 117 (1980).

Solem v. Helm. 463 U.S. 277 (1983).

United States v. One Assortment of 89 Firearms, 465 U.S. 354 (1984).

Justices of Boston Municipal Court v. Lydon, 466 U.S. 294 (1984).

Colorado v. New Mexico, 467 U.S. 310 (1984).

Ohio v. Johnson, 467 U.S. 493 (1984).

Morris v. Mathews, 475 U.S. 237 (1986).

Browning-Ferris Industries v. Kelco Disposal, 492 U.S. 257 (1989).

Grady v. Corbin, 495 U.S. 508 (1990).

Harmelin v. Michigan, 501 U.S. 957 (1991).

Alexander v. United States, 509 U.S. 544 (1993).

Austin v. United States, 509 U.S. 602 (1993).

United States v. Dixon, 509 U.S. 688 (1993).

United States v. Ursery, 518 U.S. 267, 274 (1996).

Hudson v. United States, 522 U.S. 93 (1997). 
Lewis v. United States, 523 U.S. 155 (1998).

United States v. Bajakajian, 524 U.S. 321 (1998).

Ewing v. California, 538 U.S. 11 (2003).

Lockyer v. Andrade, 538 U.S. 63 (2003).

Sattazahn v. Pennsylvania, 537 U.S. 101 (2003).

Microsoft Corp. v. i4i Ltd. Partnership, 564 U.S. 91 (2011).

Blueford v. Arkansas, 566 U.S. 599 (2012).

Timbs v. Indiana, 586 U.S. (2019).

\section{Informações adicionais e declarações dos autores (integridade científica)}

Agradecimentos (acknowledgement): This research was developed during a visiting scholar period at the Max Planck Institute for the Study of Crime, Security and Law. I would like to deeply acknowledge the Max Planck Institute, especially Professor Hörnle, Director of the Department of Criminal Law, for having granted me the opportunity that made possible the elaboration of this work.

Declaração de conflito de interesses (conflict of interest declaration): o autor confirma que não há conflitos de interesse na realização das pesquisas expostas e na redação deste artigo.

Declaração de autoria e especificação das contribuições (declaration of authorship): todas e somente as pessoas que atendem os requisitos de autoria deste artigo estão listadas como autores; todos os coautores se responsabilizam integralmente por este trabalho em sua totalidade.

Declaração de ineditismo e originalidade (declaration of originality): o autor assegura que o texto aqui publicado não foi divulgado anteriormente em outro meio e que futura republicação somente se realizará com a indicação expressa da referência desta publicação original; também atesta que não há plágio de terceiros ou autoplágio. 
Dados do processo editorial

(http://www.ibraspp.com.br/revista/index.php/RBDPP/about/editorialPolicies)

- Recebido em: 27/01/2020

- Deslocamento ao V6N2 e aviso autor: 30/01/2020

- Controle preliminar e verificação de plágio: 15/04/2020

- Avaliação 1: 30/04/2020

- Avaliação 2: 05/05/2020

- Avaliação 3: 05/05/2020

- Decisão editorial preliminar: 07/05/2020

- Retorno rodada de correções 1: 11/05/2020

- Decisão editorial preliminar 2: 12/05/2020

- Retorno rodada de correções 2: 12/05/2020

- Decisão editorial final: $17 / 05 / 2020$
Equipe editorial envolvida

- Editor-chefe: 1 (VGV)

- Editor-associado: 1 (JJEC)

- Revisores: 3

\section{COMO CITAR ESTE ARTIGO:}

ESCOBAR VEAS, Javier. The Constitutionality of Parallel Civil Forfeiture Proceedings and Criminal Prosecutions under the Double Jeopardy Clause in the United States. Revista Brasileira de Direito Processual Penal, Porto Alegre, vol. 6, n. 2, p. 701-733, mai./ago. 2020. https://doi.org/10.22197/rbdpp.v6i2.338

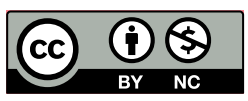

Esta obra está licenciada com uma Licença Creative Commons Atribuição-NãoComercial 4.0 Internacional. 